\title{
Reflections on 50 Years of the Sociological Study of American Jewry: Statics and Dynamics 2020 Marshall Sklare Award Address
}

\author{
Chaim I. Waxman ${ }^{1,2}$
}

Accepted: 2 June 2021 / Published online: 20 July 2021

(C) The Author(s), under exclusive licence to Springer Nature B.V. 2021

\begin{abstract}
This article looks at the first 50 years of the Association for the Sociological Study of Jewry and finds that much of its subject matter remained constant. However, there have been significant changes in perspectives. Two cases in point are the perspectives on the impact of intermarriage and on the relationship of American Jewry with Israel. A number of the reasons for the changes in perspectives are suggested.
\end{abstract}

Keywords American Jewry · Demography · Intermarriage · Israel · Jewish family · Jewish identity $\cdot$ Jewish identification $\cdot$ Prediction $\cdot$ Sklare $\cdot$ Survivalist

I owe tremendous debts of gratitude to Professors Nathan Goldberg, Deborah Offenbacher, Charles Liebman, Irving Louis Horowitz, Seymour Martin Lipset, Werner Cahnman and, in so many ways, Marshall Sklare. They were all adherents of what Sklare termed the "survivalist" perspective. They held no antipathy toward ethnoreligious particularism and they rejected assimilation. Each of them connected with me and I with them, and they encouraged me to pursue my interests in the social scientific study of Jewry. From each of them I learned to use social scientific perspectives and methods as well as my knowledge of Jews and Judaism in all of my studies.

In 1978, the Association for the Social Scientific Study of Jewry (ASSJ) published an entire issue of Contemporary Jewry on "the Sociology of Marshall Sklare." This was the only time in the history of the association that there been such a focus on the work of one individual. As Murray Binderman wrote in his "Editor's foreword,"

Chaim I. Waxman

chaim.waxman@rutgers.edu

1 Hadassah Academic College, Jerusalem, Israel

2 Rutgers University, New Brunswick, USA 
Before there was a Contemporary Jewry, even before there was an ASSJ, there was Marshall Sklare. Indeed, it is partially due to his pioneering work, his professional visibility, and his influence on two decades of students, colleagues, and peers that the ASSJ and Contemporary Jewry exist and thrive. It is only appropriate, then, that his researches, writings, and perspectives - on a field to which he helped give life-be brought to the attention of the widest possible audience. (Binderman 1977-1978)

Marshall Sklare was the epitome of a survivalist, and from his perspective, "the proper study of the sociologist is the problem of Jewish survival" (Sklare 1961, 231). Indeed, the problem of Jewish survival served as the implicit theme for his comprehensive book America's Jews, which was written for the broadest audience, especially college and university students. At the beginning of his discussion of the social characteristics of American Jews, he emphasized that those characteristics are important because they "help determine what kind of group the Jews are, what problems they face, and what the prognosis is for their survival" (Sklare 1971, 37).

Firm as he was, I also learned the need to constantly probe and rethink. In an article in the 1977-1978 issue of Contemporary Jewry dedicated to Sklare and his work, I suggested - and he subsequently stated that he was willing to agree- that his perspective on American Jewry underwent a major change (Waxman 1977-1978). In many of his addresses and writings, over a long period, he had expressed strong doubts about Jewish continuity in the United States. For example, in contrast to the sociologist C. Bezalel Sherman, who pointed to the rapid growth and expansion of temples and synagogues in second-generation Jewish suburbs as evidence of communal strength and vitality, Sklare asserted his doubts rather clearly, and pessimistically cautioned that "the true crisis occurs after the new building has been dedicated" (Sklare 1961, 235). He pointed to the possibilities of growing secularism rendering those buildings inactive and empty, and of the next generation having such strong assimilationist yearnings and strivings as to negate the survival power of the synagogues. Likewise, he cited evidence which cast strong doubts on the relationship between philanthropy and survival.

If that wasn't bleak enough, in 1964, he began the first of several articles in which he warned of the rising intermarriage rate and of the threat which it posed for "the Jewish future." Let me remind you that the evidence he cited indicated that the rate at that time, while rising, was less than $20 \%$. Intermarriage, he argued, "casts into doubt American Jewry's dual ideal of full participation in the society and the preservation of Jewish identity. And once the rate of intermarriage is seen to be growing, the contradiction in the basic strategy of American-Jewish adjustment is nakedly exposed" (Sklare 1965, 52). In 1970, Sklare reiterated the danger of intermarriage to Jewish survival and asserted that "it is a threat which overshadows all the positive developments in the American-Jewish community" and "strikes at the very core of Jewish group existence" (Sklare 1970, 51).

The rate of intermarriage did not decline after those words of warning were issued. Indeed, the rate went up and continues to do so. Nevertheless, some six years 
after issuing his warning, Sklare wrote an article in which he implied confidence in the future of American Jewry and suggested that it has and will continue to survive.

The fact that American Jewry has survived the appeal of the New Left and me counterculture. the appeal of the Old Left to East European Jews and of the Ethical Culture Movement to German Jews, the importunings of Christian missionaries (as well as dozens of other perils) will be taken by some as proof that the idea of netzach yisraeI ["the eternity of Israel"] is valid and that its validity stems from a covenant between God and Israel. Those who find such reasoning unconvincing will look to historical and to sociological factors to explain Jewish persistence. But both will agree with [Simon] Rawidowicz who pointed out that while Jews might believe that theirs is a dying people, they have refused to take the responsibility for hastening the end. Rather, they have gone about implementing heroic and extraordinary measures to prolong Jewish life. (Sklare 1976, 27)

Actually, this was not the first time that there was a shift in Sklare's perspective. An earlier one was in his implicit prognoses for the futures of Conservative and Orthodox Judaism in the United States. In 1955, in the first edition of his book Conservative Judaism, he portrayed Conservatism as the dominant Jewish religious movement in America, and he suggested that Orthodoxy was in an advanced stage of institutional decay (Sklare 1955, 43). In the 1972 edition, he wrote that "the morale of the Conservative movement is on the decline" (Sklare 1972, 261), forcing it to confront a "momentous issue," namely, that "there cannot be an authentic Jewish people without the continuity of Jewish tradition, even as there cannot be meaningful continuity of Jewish tradition without the maintenance of the integrity of the Jewish group" (282). By contrast, he averred, Orthodoxy "has transformed itself into a growing force in American Jewish life" (264).

Without getting into the specifics relating to these movements, it should be noted that one can learn from Sklare the need to be careful to observe over time, because things change. Sklare was not wrong when he saw Orthodoxy in a state of institutional decay. It was at that time, but it changed over time and, by 1972, was indeed a growing force in American Jewish life. Likewise, Sklare was not wrong when he feared for the continuity of American Judaism, but in the late 1960s and first half of the 1970s there were a number of developments which promoted American Jewish self-consciousness and identification.

I recall the text in my undergraduate Introduction to Sociology course at City College of New York, in 1959, stating that, "Human behavior is less predictable than that with which the physical sciences deal." I do not remember who the author of the text was, nor do I remember much of anything from that course, but that statement stuck with me. A more recent version of a very similar statement appears in a critique of Marx. The author wrote, "Human beings are less predictable than say, the movement of planets or the paths of falling rock" (Eubank 2011, 174).

Not long after my introductory course, I took a course in sociological theory, and at that time I understood Durkheim to be implying similarly when he suggested that, "Sociology has no need to take sides between the grand hypotheses which divide 
the metaphysicians. Nor has it to affirm free will rather than determinism. All that it asks to be granted it, is that the principle of causality should be applicable to social phenomena" (Durkheim 1982, 159). Among other things, Durkheim was saying that the sociologist can explain how and why X led to Y, but that doesn't mean that it must necessarily remain so; next year there may be a W, which is now unforeseeable, and lead-not determine-to a change from $\mathrm{Y}$ to $\mathrm{Z}$. Why is $\mathrm{W}$ unforeseeable now? Because human beings have free will, or because human beings are so complex that we can't account for all of the variables which determine their behavior; in either case, they are less predictable than that with which the physical sciences deal.

The limitations on predictability need not diminish from the value of sociology. In fact, Peter Berger suggested that, "One advantage of being a social scientist, as against being, say, a philosopher or a theologian, is that you can have as much fun when your theories are falsified as when they are verified!" Berger 1999, 2). Marshall was definitely more happy when his previous predictions about American Jewry did not turn out as he had anticipated.

The more I studied, the more I became fascinated with the phenomenon of social change, especially in the work of Weber and Durkheim, where I realized its significance. In undergraduate courses at City College of New York and Yeshiva University, I was exposed to fascinating analyses of Weber's The Protestant Ethic and the Spirit of Capitalism, Durkheim's The Rules of the Sociological Method and The Division of Labor in Society, and Ferdinand Tönnies' concepts of Gemeinschaft and Gesellschaft (Tönnies 1957), which highlighted for me the inevitability and consequences of social change even if not its direction. As a result, most of my analyses of Jews and Jewry have been within the context of social change. My first book in the area was America's Jews in Transition (Waxman 1983), and my most recent book is Social Change and Halakhic Evolution in American Judaism (Waxman 2017). Reviewing the past more than 50 years of the sociological study of Jewry, it is fascinating to see both the statics and the dynamics in the discipline.

Checking back on the articles in the very early issues of the ASSJ journal ${ }^{1}$ is very revealing, especially when seeing their subjects. For example, the first issue that has substantive articles in addition to news and reviews contained two articles. ${ }^{2}$ One, by Barry Lebowitz, was based on a representative sample of households in the Portland, Oregon metropolitan Jewish community which was collected in June and July 1971 in parallel with the National Jewish Population Survey (NJPS). The analysis covered such subjects as birthplace by age; knowledge of historical events and ideological traditions; attitudes toward traditional observances and attitudes toward political and social action; and participation in traditional practices. Contemporary analyses may be more refined and detailed, especially in statistical analyses, but the article does not appear to be much different from what we find in current articles (Lebowitz 1975).

Likewise, the following article, by Zelda Gamson, was based on a 1969 survey of kibbutz members of all ages, and provided analyses of the sources of the desire for

\footnotetext{
1 It was originally called Jewish Sociology \& Social Research, now, Contemporary Jewry.

2 The journal began as a newsletter.
} 
higher education among kibbutz members, and the response of the kibbutz movement to that desire; the then-current likely future consequences of increasing numbers of kibbutz members with advanced education; and what could be learned about egalitarian societies, generally, from the kibbutz experience with these issues (Gamson 1975). The kibbutz as it was pre-1975 essentially no longer exists but, in its style, it is the type of article that one could well expect to see in the journal today, particularly because it includes an Israeli dimension. Looking through all of the issues of the journal revealed very few significant changes. The few that were found were the result of changes in society, not in the field.

While there has not been any significant change in the subjects analyzed, there have been shifts in the perspectives relating to those subjects. There have been significant shifts in perspectives with respect to issues such as intermarriage, the Jewish family, population size, birth rate, and other demographic variables (Waxman 2019). Indeed, it is currently perceived that there is not a single perspective but, rather, numerous and varied perspectives, if for no other reason than that we see things differently. Thomas and Znaniecki implied as much in their discussion of "the definition of the situation" (Thomas and Znaniecki 1927, 68). Louis Wirth said it more explicitly when he wrote,

The distinctive character of social science discourse is to be sought in the fact that every assertion, no matter how objective it may be, has ramifications extending beyond the limits of science itself. Since every assertion of a "fact" about the social world touches the interests of some individual or group, one cannot even call attention to the existence of certain "facts" without courting the objections of those whose very raison d'etre in society rests upon a divergent interpretation of the "factual" situation. (Wirth 1936, xvii)

With respect to perspectives concerning demographic variables, Sergio DellaPergola put it somewhat more explicitly and eloquently when he wrote, "In theory, demography can claim the advantage of objectivity. In reality, demographers, like other social scientists, do make personal choices and are involved in narratives" (DellaPergola 2014, 78).

The statics and dynamics are clearly evident in the analysis of another subject which is central in the sociology of American Jews as well as in Jewish journalism during the past half-century, namely, American Jews and Israel. Much of the discussion has been concerned with the question of whether American Jews are "distancing" from Israel: Is there a growing rift between American Jewry and Israel? ${ }^{3}$

The first empirical studies of the attitudes of American Jews to Israel were in the "Lakeville Studies," by Sklare and Joseph Greenblum. As part of their study of Lakeville, they asked their respondents questions concerning feelings toward and concerns about Israel. They found that a large proportion were pro-Israel, with about $70 \%$ stating that they would feel a sense of personal loss if Israel were destroyed (Sklare and Greenblum 1967, 216). The basic study was conducted before the

\footnotetext{
${ }^{3}$ Parenthetically, it is interesting to note that much less attention was paid to the question of Israel distancing from American Jewry.
} 
Six-Day War of June 1967. After the war, they returned to Lakeville to ask specifically about attachment to Israel and found that, even if there was not an immediate and significant increase in levels of pro-Israel support, the war did have a significant impact on the Jewish life and Jewish identity of Lakeville's Jews (Sklare 1968).

On the communal level, an examination of American Jewish organizations listed annually through 2008 in the American Jewish Year Book indicated that the vast majority of them list Israel-related activities as part of their agendas. More than 80 organizations specifically devoted to Zionist and pro-Israel activities are listed, and for many others, objectives and activities such as "promotes Israel's welfare," "support for the State of Israel," and "promotes understanding of Israel" appear with impressive frequency.

A 1989 survey including "key professionals and top lay leaders from some of the most influential organizations in American Jewish life" (Cohen 1990, 14) as well as a small number of academics who were involved with Israel found that $99 \%$ of the respondents had been to Israel at least once and $84 \%$ had been there three times or more. Moreover, 78\% identified themselves as "Zionists," and 54\% had "seriously considered living in Israel." When asked, "How close do you feel to Israel?" $78 \%$ responded "very close" and 19\% "fairly close." Only $2 \%$ stated that they felt "fairly distant" and none stated "very distant."

Not only do most Jewish leaders feel close to Israel and identify with Zionism in the American sense of that term - that is, pro-Israelism ${ }^{4}$ - they also appear to subscribe to the Zionist tenet of the centrality of Israel. Thus, in response to the statement "Jewish life in America is more authentically and positively Jewish than Jewish life in Israel," $81 \%$ of the sample disagreed and only $10 \%$ agreed (26-28).

The ways in which Jewish organizations have been strongly involved in defense activity for Israel have been amply documented (Elazar 1995; Woocher 1986). Israel also became increasingly central in the realm of American Jewish education. If, in 1968, Schiff found that Israel was taught as a separate subject in $48 \%$ of all Jewish schools, including all-day, weekday afternoon, and one-day-a-week schools under Orthodox, Conservative, Reform, communal, and secular auspices (Schiff 1968), Chazan found by 1974 that $63 \%$ of the school curricula listed Israel as a separate subject, with "a general increase of attention paid to Israel in all subject-areas as compared with 1968" (Chazan 1979).

The prayer for the State of Israel became an integral part of the Sabbath morning service in increasing numbers of Conservative and Orthodox synagogues, and a special prayer for Israel's Independence Day, Yom Ha-atzmaut, was introduced into Reform Judaism's officially approved prayer book, Gates of Prayer (Central Conference of American Rabbis 1975). Hebrew literature (in English translation) and Israeli songs became central in the culture of American Jews. In large measure, by the middle of the 1970s, traditional Yiddish-based East European Jewish culture had been largely supplanted by the forms and symbols of modem Israel.

In his 1986 analysis, Gilboa found that support for Israel remained high within the American Jewish community and was seen as strong enough to have weathered severe challenges such as the Israeli war in Lebanon and outright Israeli rejection of various US-sponsored Middle East peace proposals (Gilboa 1986). 
In 2012, Ira Sheskin presented a detailed analysis from findings in both national and local Jewish community studies, and focused on two aspects of the "distancing hypothesis." One issue was whether younger American Jews were less attached to Israel than their older peers, and the other issue was whether there had been an overall decline in American Jewish emotional attachment to Israel over time. The national studies between 1996 and 2010 supported the first hypothesis of declining attachment to Israel among younger American Jews. As for the second hypothesis, that there was an overall decline in American Jewish attachments to Israel, the findings were mixed. Cohen and Kelman (2010), whose data indicated decline, attributed it primarily to intermarriage. They argued that the intermarriage rate among non-Orthodox America Jews rose consistently by decade and cohort; Jews who were intermarried were much less attached to Israel than were those who were in-married; children of intermarriage were much less attached to Israel than were those with two Jewish parents; and there was a growing gap in attachment to Israel between those who were intermarried and those who were not (Cohen and Kelman, 290-291). The local Jewish community data also showed support for the decline among younger American Jews, although not as strongly as the national studies did, but no support for the hypothesis that the attachments of America's Jews to Israel had been decreasing over time. With respect to both hypotheses, Sheskin found significant geographic variations, in both the national and the local Jewish community studies, in levels of emotional attachment to Israel (Sheskin 2012:58-59).

The 2013 Pew survey of American Jews revealed no declining attachments and, in fact, there were some indications of increased attachments. When asked, "How emotionally attached are you to Israel?" 69\% said that they were very or somewhat attached, of which $30 \%$ said that they were very attached (Pew Research Center 2013, 13). Almost half of American Jews by religion (49\%), as compared to only $23 \%$ of those of no religion, indicated that they visited Israel at least once. In total, $43 \%$ of America's Jews had visited at least once, and $23 \%$ had done so more than once (Pew Research Center 2013, 85). This was a significant increase over what was indicated in previous surveys, from the $15 \%$ in NJPS 1971, $22 \%$ in NJPS 1990, and $41 \%$ in NJPS 2000-2001. Part of this increase may be a result of the increasing ease of international travel (Rebhun et al. 2020, 20), and part of it may be due to the influence of Taglit-Birthright Israel which, since 1999, has been sponsoring trips to Israel for young American Jews aged 18-32, which have been shown to have a positive impact on feelings of connection and involvement with Israel (Saxe et al. 2009, 14-19; Wright et al. 2020, 14-15).

Corroborating the findings of Sheskin (2012), the 2013 Pew survey of Jewish Americans indicated that those raised by two Jewish parents were more likely to be strongly attached to Israel (36\%) than were those raised by one Jewish parent $(24 \%)$ (Rebhun et al. 2020, 24). Denominationally, the survey showed that the Orthodox were the most strongly attached, with $61 \%$ stating that they were very emotionally attached, as compared to "Other Jews," of whom $27 \%$ were very emotionally attached (Pew 2013, 24).

There are two areas in which there are strong disagreements between large sectors of American Jewry and Israel, namely, religion and politics. In 2017, Steven Bayme, who was then director of the Contemporary Jewish Life Department at the 
American Jewish Committee, pointed to two religion-related issues which he saw as "what is arguably the single greatest rift in Israel's relations with American Jewry," over the past quarter-century and more (Bayme 2017). The specific issues were the Israeli government's reneging on an agreement which was to guarantee equal access to the Western Wall for egalitarian prayer services, and the non-recognition as Jews of many whose Jewish status had been certified by American rabbis.

Although these and other religious issues in Israel are very disturbing to many if not most American Jews, a 2016 survey by the American Jewish Committee found that less than half, $48 \%$, of America's Jews thought that "the fact that Orthodox Judaism is the only denomination recognized by Israel as an official form of Judaism... weakens Israel's ties with American Jews" (AJC 2016) Especially in light of the fact that the overwhelming majority, 88-90\%, of America's Jews are not Orthodox, the extent to which the actions of Israel's Orthodox monopoly weakens ties with America's Jews appears to be limited.

Perhaps an even greater and more basic divide between American and Israeli Jews is in sociopolitical perspectives which are rooted in geography and very different conceptions of what type of group Jews constitute and what role Judaism plays in defining that identity. As Gordis avers, Israel, like all of the countries in the Middle East, is primarily nationalistic rather than universalistic, and most Jews in Israel view Jews as a nation that has returned to history and its rightful ancestral homeland, a state of and for the Jewish people, with Judaism being the history and culture of its people. American Jews, by contrast, are part of a society that strives for universalism. To most of them, Judaism is a religion practiced within a society in which faith is an entirely personal matter (Gordis 2019).

Geography plays an additional strong role in the difference between American Jewish and Israeli sociopolitical perspectives. Alexis de Tocqueville pointed out long ago the contribution to stability provided by America's being protected on its eastern and western sides by oceans (Tocqueville 1835, 260-261) American Jews live in a country with a history of stability. Other than the Civil War, the wars in which it was involved took place abroad. Israel, by contrast, exists in a region rife with conflict and has a history of being surrounded by enemies who constantly challenge its very existence.

It is thus not surprising that Israeli Jews are much less positive about the prospects for peace between Israel and the Palestinians than are American Jews. For example, less than half, only slightly more than $40 \%$, of Israeli Jews believe in the feasibility of a two-state solution which will result in peaceful coexistence between Israel and an independent Palestinian state. American Jews are much more supportive of a two-state solution, and that support grew from $42 \%$ in 1998 to about 61 in $2015 \%$. Perhaps not surprisingly, the greater optimism of America's Jews about the possibility of peace in the Middle East and its actual stalemate has led to their greater skepticism of Israel's sincerity in the issue. Around 38\% of American Jews believe that the Israeli government is making a sincere effort to bring about peace, compared with a clear majority, 56\%, of Israeli Jews (Rebhun et al. 2014, 2020).

The relative stability of favorable American Jewish attitudes toward Israel was most recently shown in a 2019 survey by the Ruderman Family Foundation. It found that more than $40 \%$ (44\%) had visited Israel, and $67 \%$ said that they were 


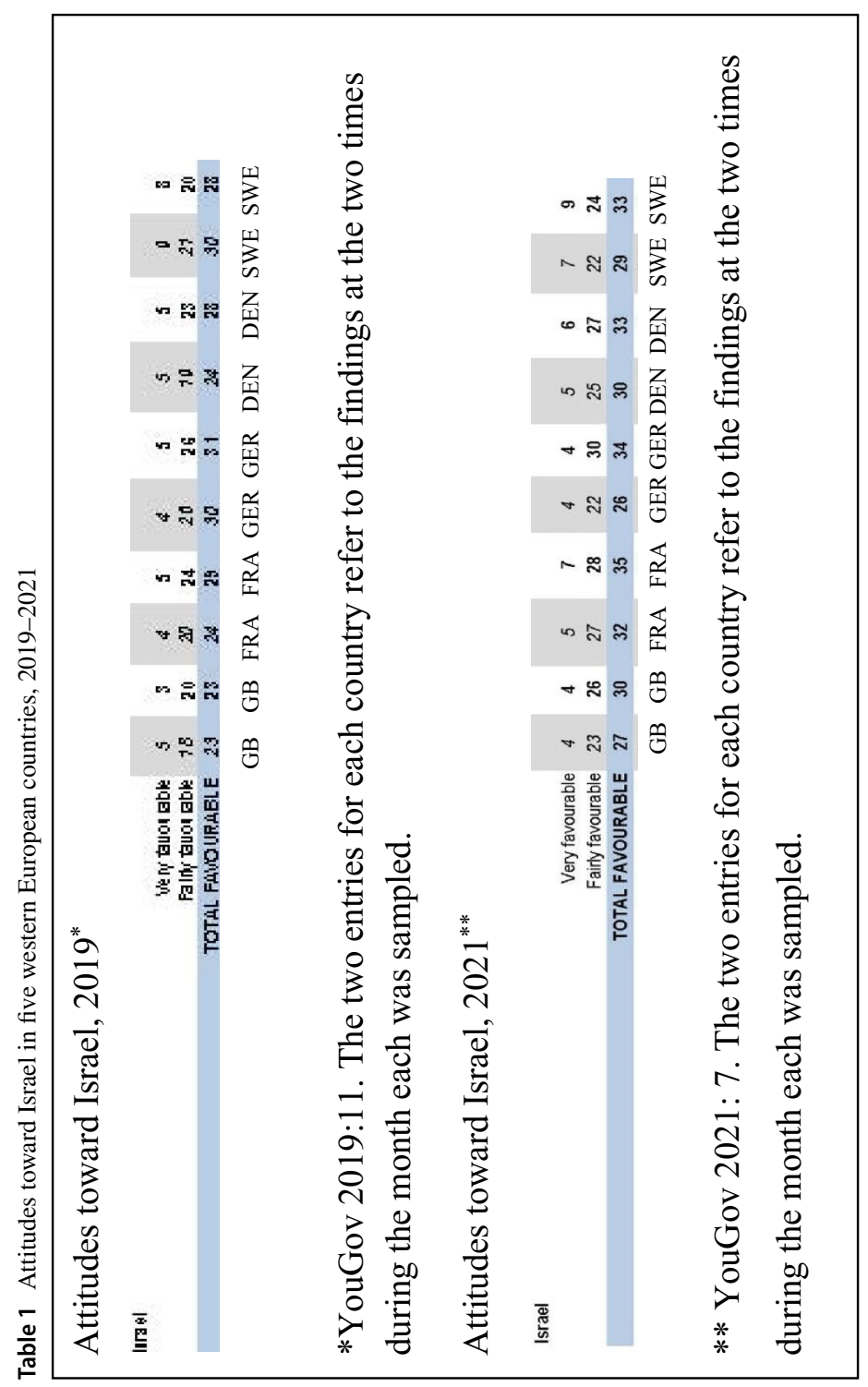


emotionally attached to Israel and felt their own attachment was at least as strong as it had been five years ago. Of those who were attached, more than $25 \%$ said they were "very attached." Also, there was very little difference in degree of attachment between those under age 40 and those 60 and above. Significantly, $80 \%$ of American Jews said they were pro-Israel even as they were critical of the Israeli government (Ruderman Family Foundation 2019).

Mention was made previously of the limits of predictability in sociology. For the purposes of the current issue, namely, American Jewish attitudes and attachments toward Israel, it should be emphasized that changes may occasionally occur because the entire region in which Israel is situated has a history of rapid changes. For example, the research data and analytics group, YouGov, which annually tracks attitudes toward various countries, found that favorable attitudes toward Israel had increased significantly between 2019 and 2021 in western European countries, including Great Britain, France, Germany, Denmark, and Sweden, especially because of the signing of the Abrahamic Accords and Israeli achievements with the COVID-19 vaccinations (Table 1).

If such attitudes of western European countries toward Israel change so rapidly, it seems reasonable to assume that the attitudes and attachments of American Jews toward Israel can also change rapidly. For example, a 50\% increase in applications of American Jews to make aliyah was reported several months after the COVID19 outbreak in 2020 (Sharon 2020). Although those who anticipated the increase were disappointed when it did not materialize, that there was a significant increase in those contemplating imminent immigration to Israel because of the coronavirus demonstrates that unforeseen factors can significantly complicate prediction.

Although American Jewish attitudes and connections to Israel have remained relatively stable over the years, there has been a significant change in the sense of legitimacy to publicly challenge policies of Israel and to publicly criticize Israel. That may be a reflection of a broader American pattern of challenging authority; it may be a reflection of American Jews' sense of Israel security; and it may be a reflection of the growing public criticism of government policies within Israel, with increasing numbers of American Jews feeling that, "If they can so publicly criticize, so can we." Prior to 1990 , there were no internet sites, including Israeli's online Haaretz and Jerusalem Post, and accessibility to knowledge of the day-to-day happenings in Israel was very limited. Since then, anyone with any interest in Israel can get a picture, even if distorted, of what is happening in contemporary Israel and how many different factions within the society are actively and loudly protesting government policies.

Having mentioned my college Introduction to Sociology course text that spoke of some of the limitations in predictability, and being aware of the Talmudic statement by Rabbi Yochanan that, "From the time that the Beit Hamikdash (the Temple in Jerusalem) was destroyed, prophecy was taken away from the prophets and given to fools and babies" (Baba Batra 12b), I will not predict what the data in the delayed but yet forthcoming 2020 Pew study will show. It will surely provide much data for us to analyze and debate. I suspect that Marshall would turn to his faith in netzach yisrael and his hope that both American and Israeli Jews will implement heroic and extraordinary measures to prolong the attachments. 


\section{References}

AJC. 2016. Survey of American Jewish Opinion. http://www.ajc.org/site/c.7oJILSPwFfJSG/b.9456115/k. F87D/AJC_Survey_of_American_Jewish_Opinion_2016.htm. Accessed 10 Feb 2020.

Bayme, Steven. 2017. Israel and American Jewry: Can the rift be healed? https://www.jpost.com/opinion/ israel-and-american-jewry-can-the-rift-be-healed-499872. Accessed 18 July 2017.

Berger, Peter L., ed. 1999. The desecularization of the world: Resurgent religion and world politics. Grand Rapids, MI: Eerdmans.

Binderman, Murray B. 1977-1978. Editor's foreword. Contemporary Jewry 4(1):2.

Central Conference of American Rabbis. 1975. Gates of prayer. New York: CCAR Press.

Chazan, Barry. 1979. Israel in American Jewish schools revisited. Jewish Education 47 (2): 7-17.

Cohen, Steven M. 1990. Israel-Diaspora relations: A survey of American Jewish leaders. Ramat Aviv: Israel-Diaspora Institute 1990: 14.

Cohen, Steven M., and Ari Y. Kelman. 2010. Thinking about distancing from Israel. Contemporary Jewry 30 (2-3): 287-296.

DellaPergola, Sergio. 2014. My narratives: Discipline, profession, ideology, and policy. Contemporary Jewry 34: 75-91.

Durkheim, Emile. 1982. The Rules of the Sociological Method. ed. Steven Lukes. Trans. W.D. Halls. New York: Free Press.

Elazar, Daniel J. 1995. Community and polity: The organizational dynamics of American Jewry. Philadelphia: Jewish Publication Society.

Eubank, Lawrence. 2011. Why Marx was wrong. Bloomington, IN: AuthorHouse.

Gamson, Zelda F. 1975. The kibbutz and higher education: Cultures in collision? Contemporary Jewry 2 (1): 10-28.

Gilboa, Eytan. 1986. Israel in the mind of American Jews: Public opinion trends and analysis. Research Report 4. London: Institute of Jewish Affairs.

Gordis, Daniel. 2019. We stand divided: The rift between American Jews and Israel. New York: HarperCollins.

Lebowitz, Barry D. 1975. Migration and the structure of the contemporary Jewish community. Contemporary Jewry 2 (1): 3-9.

Pew Research Center. 2013. A portrait of Jewish Americans: Findings from a Pew Research Center Survey of U.S. Washington, DC: Jews.

Rebhun, Uzu, Nadia Beider, and Chaim I. Waxman. 2020. Jews in the United States and Israel: A comparative look upon Israel's 70th anniversary. American Jewish Year Book 2019, ed. A. Dashefsky, I. M. Sheskin, 3-37.

Rebhun, Uzi, Chaim I. Waxman, and Nadia Beider. 2014. American Jews and the Israeli-Palestinian peace process: A study of diaspora in international affairs. In Reconsidering Israel-Diaspora Relations, ed. E. Ben-Refael, J. Bokser Liwerant, and Y. Gorny. Boston: Brill.

Ruderman Family Foundation. 2019. American Jewry position survey. https://rudermanfoundation.org/ white_papers/american-jewry-survey/. Accessed 11 Mar 2021.

Saxe, Leonard, Benjamin Phillips, Theodore Sasson, Shahar Hecht, Michelle Shain, Graham Wright, and Charles Kadushin. 2009. Generation birthright Israel: The impact of an Israel experience on Jewish identity and choices. Waltham, MA: Brandeis University, Cohen Center for Modern Jewish Studies.

Schiff, Alvin I. 1968. Israel in American Jewish schools: A study of curriculum realities. Jewish Education 38 (4): 6-24.

Sharon, Jeremy. 2020. 50\% rise in aliyah applications from US, and more expected. https://www. jpost.com/diaspora/50-percent-rise-in-aliyah-applications-from-us-jewish-agency-expects-more626900. Accessed 8 May 2020.

Sheskin, Ira M. 2012. Attachment of American Jews to Israel: Perspectives from local Jewish community studies. Contemporary Jewry 32: 27-65.

Sklare, Marshall. 1955. Conservative Judaism: An American religious movement. Glencoe, IL: Free Press.

Sklare, Marshall. 1961. American Jews and American Jewish life: Observations of a sociologist. Central Conference of American Rabbis Yearbook 71: 229-244.

Sklare, Marshall. 1965. Intermarriage \& the Jewish future. Commentary 37 (4): 46-52.

Sklare, Marshall. 1968. Lakeville and Israel: The Six-Day War and its aftermath. Midstream 14 (8): 1-19.

Sklare, Marshall. 1970. Intermarriage and Jewish survival. Commentary 49 (3): 51-58. 
Sklare, Marshall. 1971. America's Jews. New York: Random House.

Sklare, Marshall. 1972 Conservative Judaism: An American religious movement, new augmented ed. New York: Shocken Books.

Sklare, Marshall. 1976. American Jewry-The ever dying people. Midstream 22 (6): 17-27.

Sklare, Marshall, and Joseph Greenblum. 1967. Jewish Identity on the suburban frontier: A study of group survival in the open society. New York: Basic Books.

Thomas, William I., and Florian Znaniecki. 1927. The Polish peasant in Europe and America, vol. 1. New York: Alfred A. Knopf/.

Tocqueville, Alexis de. 1835. Democracy in America, Vol. 1. Trans. Henry Reeve, Esq. London: Saunders and Otley.

Tönnies, Ferdinand, 1957. Community \& Society (Gemeinschaft Und Gesellschaft). Trans. Charles P. Loomis. East Lansing, MI: Michigan State University Press.

Waxman, Chaim I. 1977-1978. Psalms of a sober man. Contemporary Jewry 4(1):3-11.

Waxman, Chaim I. 1983. America's Jews in transition. Philadelphia, PA: Temple University Press.

Waxman, Chaim I. 2017. Social change and halakhic evolution in American Orthodoxy. Liverpool, UK: Littman Library of Jewish Civilization/Liverpool University Press.

Waxman, Chaim I. 2019. Family and identity: Marshall Sklare, the social scientific study of America's Jews, and Jewish communal policy. Contemporary Jewry 39: 379-406.

Wirth, Louis. 1936. Preface. In Ideology and utopia, ed. Karl Mannheim. London: Routledge \& Kegan Paul.

Woocher, Jonathan S. 1986. Sacred survival: The civil religion of American Jews. Bloomington: Indiana University Press.

Wright, Graham, Shahar Hecht, and Leonard Saxe. 2020. Jewish Futures Project. Birthright Israel's first decade of applicants: A look at the long-term program impact. Waltham, MA: Brandeis University, Cohen Center for Modern Jewish Studies.

YouGov. 2019. YouGov survey results. https://d25d2506sfb94s.cloudfront.net/cumulus_uploads/docum ent/wrwqubhp5c/Feb2019_ToplineResults_final_w.pdf. Accessed 23 March 2021.

YouGov. 2021. YouGov/Eurotrack survey results. https://docs.cdn.yougov.com/zdhqxsts2n/Eurotrack_ Feb21_Topline.pdf. Accessed 23 Mar 2021.

Publisher's Note Springer Nature remains neutral with regard to jurisdictional claims in published maps and institutional affiliations.

Chaim I. Waxman is Professor and Chair of the Department of Behavioral Sciences at Hadassah Academic College in Jerusalem; Professor Emeritus of Sociology and Jewish Studies, Rutgers University.; and a former president of the Association for the Sociological Study of Jewry. He did his undergraduate work at City College of New York and Yeshiva University, and his graduate work at The New School for Social Research. He specializes in the sociological study of Jews and Judaism, including America's Jews, Orthodox Jewry, Jewish identity and identification, Israeli society and culture, and Zionism. 